\title{
PEAT AS A SOURCE OF NITROGEN FOR PLANTS IN POT CULTURE
}

\author{
Erkki Kivinen and Armi Kaila
}

University of Helsinki, Department of Agricultural Chemistry

Received July 16, 1958

In a previous paper (3) the authors reported results from mineralization of peat nitrogen in incubation experiments. It was found that prolonged incubation even at room temperature brought about a marked accumulation of mineral nitrogen in most of the samples studied. A large part of this nitrogen was in the form of nitrate in spite of the marked acidity of several samples.

The experiments the results of which are recorded in the present paper have been carried out in order to test the ability of peat samples of different kind to supply plants with nitrogen. An objective of this paper will also be the consideration of the correspondence of the results of incubation experiments and the actual uptake of peat nitrogen by plants.

\section{Material}

The material of the present study consists of eight samples from virgin peat lands. Four of the samples represented tillable peat lands or soils with the virgin productivity higher than 5 in the scale from 1 to 10 . The other samples originated from peat lands of a poor quality. The samples were the same used in the previous study (3) in which information of their origin is reported in more detail.

The samples were air-dried and ground in a Wiley mill. They were analyzed for total nitrogen by the common Kjeldahl procedure. Ammonium nitrogen and nitrate nitrogen were determined with the methods reported in the previous paper (3). These data are listed in Table 1, and they are expressed on the volume basis in order to get somewhat nearer to the natural conditions.

The content of total nitrogen is fairly high in most of the samples, even when expressed on the volume basis. The weight of volume in these samples varied from 0.1 to 0.3 which means that the data would have been far higher if the results were reported per weight units. Only sample 1.Sp is poor in nitrogen. Also the relatively 
Table 1. Peat samples and their content of nitrogen

\begin{tabular}{lccccccc}
\hline Sample & $\mathrm{H}^{1}$ & $\mathrm{Bo}^{2}$ & $\mathrm{pH}$ & $\begin{array}{r}\text { Kjeldahl } \\
\mathrm{N} \mathrm{mg} / \mathrm{l}\end{array}$ & $\begin{array}{c}\mathrm{NH}_{4}-\mathrm{N} \\
\mathrm{mg} / \mathrm{l}\end{array}$ & $\begin{array}{c}\mathrm{NO}_{3}-\mathrm{N} \\
\mathrm{mg} / \mathrm{l}\end{array}$ & $\begin{array}{c}\text { Mineral N } \\
\mathrm{mg} / \mathrm{l}\end{array}$ \\
\hline 1. Sp & 1 & 1 & 4.0 & 1240 & 23 & 12 & 35 \\
2. CSp & 3 & 2 & 4.7 & 8070 & 54 & 16 & 80 \\
3. LCSp & 4 & $2-3$ & 4.5 & 6670 & 94 & 19 & 113 \\
4. CSp & 4 & 3 & 4.5 & 7950 & 40 & 12 & 52 \\
5. SCp & 4 & 6 & 4.7 & 8420 & 57 & 8 & 65 \\
6. LCp & 4 & 7 & 4.9 & 8850 & 70 & 14 & 84 \\
7. BCp & 2 & 7 & 4.7 & 6640 & 25 & 13 & 38 \\
8. EuSCp & 3 & 8 & 5.6 & 4640 & 23 & 32 & 55 \\
\hline
\end{tabular}

1 Degree of humification by von Post from 1 to 10.

2 Virgin productivity from 1 to 10 .

low nitrogen content in the samples 7.BCp and $8 . \mathrm{EuSC}$ originating from peat lands of a good quality draws attention.

Owing to the air-drying and grinding of the samples, probably a marked mineralization of peat nitrogen has already occurred in most of them (cf. 5). Although the amounts of mineral nitrogen are high, they do not, however, correspond to more than 0.5 to 3 per cent of the total nitrogen content. Particularly in sample 3.LCSp a marked amount of mineral nitrogen was found. Also samples 2.CSp and 6.LCp are rich in mineral nitrogen. The lowest contents of mineral nitrogen occur in samples 1.Sp and 7.BCp.

\section{Pot experiment}

In the pot experiment carried out in order to study the availability of peat nitrogen to plants, four successive oat crops were grown with peat as the only source of nitrogen. One liter of air-dry and ground peat was mixed with four liters of washed quartz-sand and put into Mitscherlich-pots. All the eight peat samples were treated in four replications.

The experimental plant was "Kultasade II" oat. 50 seeds were sown in each pot. After the sprouting they were thinned to 35 plants per pot. The sowing was performed in the beginning of June, and the ripen plants were harvested in the end of August or in the beginning of September. After the harvest the peat and sand mixtures were allowed to get dry, and they were stored in pots until the following spring. Then the roots were removed by sieving.

In the first year fertilizers were applied in the following amounts per pot: $0.5 \mathrm{~g}$ of superphosphate and $0.25 \mathrm{~g}$ of $50 \%$ potash salt. Also $4 \mathrm{~g}$ of calcium carbonate was mixed with the soil. In the second year the same amounts of superphosphate and potash salt were used as in the first year. In addition to these $0.225 \mathrm{~g}$ of magnesium sulphate and $0.025 \mathrm{~g}$ of copper sulphate were applied. In the following two years only a phosphate and potash salt dressing was given. 
Both the grain yield and the straw yield were weighed and analyzed for total nitrogen by the common Kjeldahl procedure. The roots were removed without analysing them.

The results of the first year are reported in Table 2. There are to be found significant differences between the yields produced by the various peat samples. The low grain yield in pots of sample 6.LCp may be attributed to the copper defic-

Table 2. Yields and nitrogen content of the first oat crop

\begin{tabular}{|c|c|c|c|c|c|}
\hline Sample & $\begin{array}{l}\text { Grain } \\
\text { yield } \\
\text { g/pot }\end{array}$ & $\begin{array}{c}\mathrm{N} \text { in } \\
\text { grain } \\
\%\end{array}$ & $\begin{array}{l}\text { Straw } \\
\text { yield } \\
\text { g/pot }\end{array}$ & $\begin{array}{c}\mathrm{N} \text { in } \\
\text { straw } \\
\%\end{array}$ & $\begin{array}{c}\mathrm{N} \text { in } \\
\text { yield } \\
\mathrm{mg} / \text { pot }\end{array}$ \\
\hline 1. $\mathrm{Sp}$ & 4.2 & 1.35 & 6.0 & 0.22 & 70 \\
\hline 2. CSp & 7.2 & 1.58 & 8.6 & 0.24 & 133 \\
\hline 3. LCSp & 5.3 & 1.85 & 6.1 & 0.35 & 118 \\
\hline 4. $\operatorname{CSp}$ & 3.7 & 1.61 & 4.4 & 0.27 & 71 \\
\hline 5. $\mathrm{SCp}$ & 6.2 & 2.14 & 10.0 & 0.55 & 188 \\
\hline 6. $\mathrm{LC}_{\mathrm{p}}$ & 3.3 & 2.67 & 9.7 & 0.83 & 170 \\
\hline 7. $\mathrm{BC}_{\mathrm{p}}$ & 5.7 & 1.36 & 7.4 & 0.24 & 95 \\
\hline 8. EuSCp & 4.1 & 1.37 & 5.8 & 0.24 & 70 \\
\hline L.S.D. $5 \%$ & 0.9 & 0.14 & 0.7 & 0.05 & 15 \\
\hline
\end{tabular}

iency. In the following year when copper sulphate had been applied no such symptoms could be detected in the plants. In spite of this poor development of grains the plants in pots of sample 6.LCp have been able to take up a marked amount of nitrogen. In this respect sample 6.LCp is second to sample 5.SCp. Poor growth and low nitrogen uptake characterize plants in the pots of samples 4.CSp, 8.EuSCp, and 1.Sp. Sample 2.CSp has produced a relatively high crop with a nitrogen content which makes it the third in order as a supplyer of nitrogen. Sample 7.BCp proves to be no good source of nitrogen for oats although the grain and straw yields are not low. Even sample 3.LCSp is markedly better than it, if nitrogen yields are considered.

The nitrogen content in the seed was about 1.6 per cent. Samples 1.Sp, 7.BCp and $8 . E u S C p$ have not been able to produce grains with a nitrogen content equal to that of the seed. In the pots of sample 5.SCp, on the other hand, the grain is rich in nitrogen. Straw appears to be very low in nitrogen in all the other pots except in those of samples 5.SCp and 6.LCp. This indicates that the plants in most of the pots have suffered from deficiency of available nitrogen.

In Figure 1 the grain and straw yields of the four successive crops are presented. Although, in general, a tendency to decrease may be found with the years the patterns for various peat samples show marked differences. Sample 1.Sp seems to have been depleted already in the first year. Samples 4.CSp and 6.LCp have been able to maintain the level of their first crop for almost three years. Samples 2.CSp, 7.BCp and 8.EuSCp have increased their yields again in the third year after a more or less marked drop from the original level in the second year. A steady decrease may be 


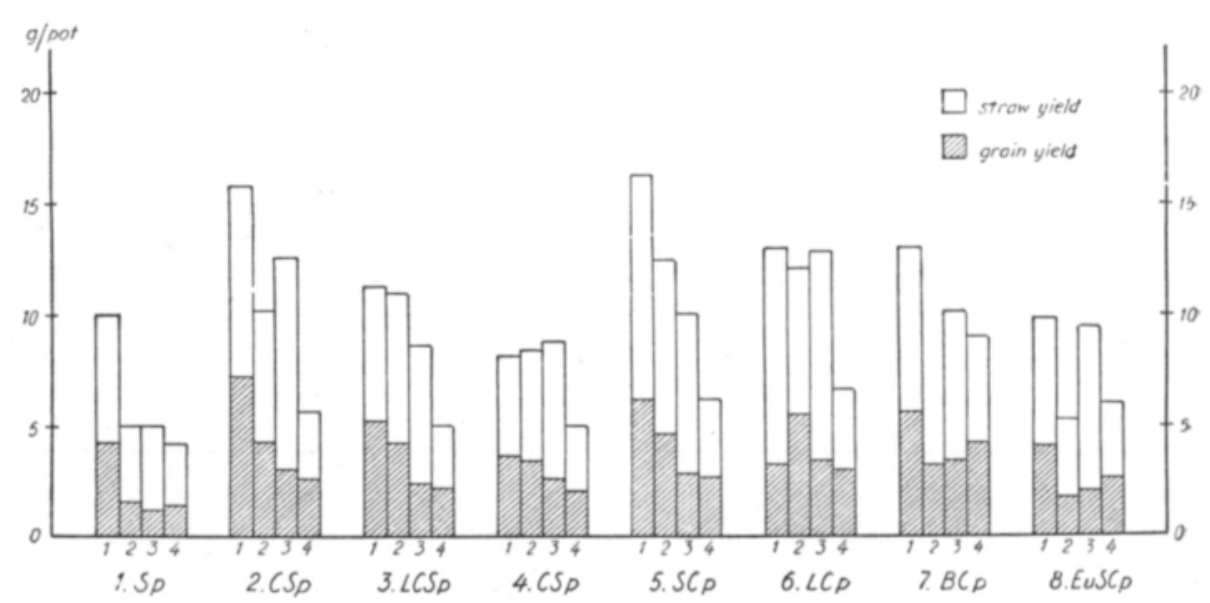

Fig. 1. Grain and straw yields of the four successive oat crops.

found in the yields of the pots of sample 5.SCp. Generally, the yield in the fourth year is very poor.

As to the total yields produced in the four years the good result given by the sample 2.CSp is worth of attention. It is equal to that of the samples 5.SCp and 6.LCp. Surprisingly poor is the yield from the pots of the sample 8.EuSCp. It is not significantly higher than that of the sample 4.CSp. Somewhat better are the yields of samples 3.LCSp and 7.BCp. The lowest, of course, are the yields of sample 1.Sp.

The main object of this experiment was, however, to study the amounts of nitrogen which the plants are able to take up from these peat samples. The estimation of these quantities is not quite easy on the basis of the available data. Allowence must be made to the amount of nitrogen in the seed oats. It can be calculated that the 35 seeds remaining in the pots after the thinning contain about $18 \mathrm{mg}$ of nitrogen. It is, of course, possible that a part of nitrogen from the 15 seeds removed was left in the soil. On the other hand, some nitrogen was removed in the roots which were sieved away. Assuming that these amounts are almost equal, we may suppose that the part of nitrogen in the harvested yield which originated from the seed oats corresponds to $18 \mathrm{mg} /$ pot.

On the basis of this assumption the uptake of nitrogen from the peat samples by the four successive oat crops may be presented by the figures in Table 3 . The mutual order of the samples in the first summer is, of course, the same as in Table 2. It is of interest to notice that the plants have been able to take up from the samples 1.Sp, 4.CSp and 8.EuSCp only half of the amount of nitrogen they obtained from the samples 2.CSp and 3.LCSp, and about one third of the quantities of nitrogen delivered by the samples 5.SCp and 6.LCp.

Only sample 4.CSp has been able to maintain its level of nitrogen supply also in the second year. For all the other samples a marked drop has occurred. Sample 6.LCp is now the best supplyer of nitrogen, the following in order are samples $5 . \mathrm{SC}_{\mathrm{p}}$ and 4.CSp. The data for samples 3.L.CSp and 2.CSp are not markedly lower than that for sample 4.CSp. Sample 7.BCp has released no nitrogen to the plants, and also the amounts from samples 1.Sp and 8.EuSCp are very low. 
The third crop has taken up lower amounts of nitrogen than the second one from all the other samples except 7.BCp and 8.EuSCp. The same is the case also between the data found for the fourth crop and the third crop. In the last year sample 7.BCp has been the best supplyer of nitrogen.

The total amounts of nitrogen taken up by all the four crops are fairly high in several samples. This will be more apparent if it is remembered that the figures in Table 3 must be multiplied by two in order to get the amounts of nitrogen ex-

Table 3. Uptake of peat nitrogen by four successive oat crops (Expressed as $\mathrm{N} \mathrm{mg/pot} \mathrm{or} \mathrm{mg/l} \mathrm{of} \mathrm{peat)}$

Sample

1. crop

2. crop

3. crop

4. crop

Total

\begin{tabular}{lrrrrr} 
1. Sp & 52 & 16 & 10 & 1 & 79 \\
2. CSp & 115 & 46 & 41 & 23 & 225 \\
3. LCSp & 100 & 57 & 27 & 13 & 197 \\
4. CSp & 53 & 66 & 28 & 19 & 166 \\
5. SCp & 170 & 73 & 33 & 18 & 294 \\
6. LCp & 152 & 99 & 58 & 26 & 335 \\
7. BCp & 77 & 2 & 39 & 58 & 176 \\
8. EuSCp & 52 & 20 & 26 & 29 & 127 \\
\hline L.S.D. 5 \% & 15 & 14 & 15 & 15 & 17
\end{tabular}

pressed as $\mathrm{kg} / \mathrm{ha}$. Attention must, of course, be paid to the fact that the conditions of this kind of pot experiment are far more favourable than those in nature. It is probable that after reclamation some of the peat lands the samples of which was studied are not able to produced satisfactory yield without application of nitrogen fertilizers.

The mutual order of these peat samples as supplyer of nitrogen in pot experimet is on the basis of the total amounts the same as in the first year with the exception that sample 6.LCp is better than sample 5.SCp. This probably, may be attributed to the copper deficiency in sample 6.LCp in the first year.

\section{Incubation experiment}

The mineralization of nitrogen in these peat samples has been studied by several incubation experiments under different conditions. In the present paper results are reported from two experiments carried out at fairly low temperatures.

In the first of the experiments the samples were incubated at $7^{\circ} \mathrm{C}$ for four months. In the other one the incubation temperature varied from 10 to $15^{\circ} \mathrm{C}$ and the experimental periods were one month and six months. The experiments were carried out and analyzed in the same way as those reported in the previous paper (3.) Both of the experiments included several treatments. Since in connection of the present study the most interesting data are those obtained by the same treatments used in the pot experiment results from the other treatments are not recorded. 
Table 4. Mineral nitrogen in incubated peat samples (Expressed as $\mathrm{mg} / \mathrm{l}$ of soil)

\begin{tabular}{|c|c|c|c|c|c|}
\hline \multirow{3}{*}{ Sample } & \multicolumn{3}{|c|}{ Incubated at $7^{\circ} \mathrm{C}$ for 4 months } & \multicolumn{2}{|c|}{ Incubated at $10-15^{\circ} \mathrm{C}$ for } \\
\hline & & & & 1 month & 6 months \\
\hline & $\mathrm{NH}_{4}-\mathrm{N}$ & $\mathrm{NO}_{4}-\mathrm{N}$ & Mineral N & Mineral $\mathrm{N}$ & Mineral N \\
\hline 1. Sp & 52 & 3 & 55 & 40 & 80 \\
\hline 2. CSp & 184 & 16 & 200 & 110 & 430 \\
\hline 3. LCSp & 210 & 25 & 235 & 195 & 320 \\
\hline 4. $\operatorname{CSp}$ & 119 & 9 & 128 & 100 & 405 \\
\hline 5. $\mathrm{SC}_{\mathrm{p}}$ & 294 & 52 & 346 & 210 & 555 \\
\hline 6. $\mathrm{LC} p$ & 302 & 23 & 325 & 210 & 405 \\
\hline 7. $\mathrm{BC}_{\mathrm{p}}$ & 97 & 8 & 105 & 85 & 370 \\
\hline 8. EuSCp & 78 & 4 & 82 & 105 & 160 \\
\hline
\end{tabular}

When the data of the first incubation experiment reported in Table 4 are compared with the original mineral nitrogen content of the samples found in Table 1, it cannot be denied that a marked increase, in total mineral nitrogen content of all the samples has occurred. This is mostly due to the accumulation of ammonium nitrogen. In several samples even a decrease in the nitrate nitrogen content is obvious. Probably this may be attributed to some kind of denitrification, since the microorganisms which immobilize mineral nitrogen in decomposing organic matter are shown to prefer ammonium nitrogen for the nitrate form (1), and enough ammonium nitrogen was available in these samples. Only in sample 5.SCp nitrate nitrogen has accumulated in a marked degree.

The data obtained in the second experiment owing to incubation for one month at $10-15^{\circ} \mathrm{C}$ are somewhat lower than those of the first experiment which lasted for four months but was carried out at a lower temperature. In six months at the higher temperature the accumulation of mineral nitrogen has, however, markedly exceeded the amounts found in the first experiment. It may be mentioned that mineral nitrogen in the samples only incubated for one month was mostly in the form of ammonium nitrogen, whereas in the samples incubated for six months most of the mineral nitrogen fraction consisted of nitrate nitrogen except in the samples 1.Sp and 4. CSp.

\section{Comparison of the results of pot culture and incubation experiment}

In order to facilitate the comparison of the amounts of peat nitrogen taken up by the four crops with the results of the incubation experiments the data are presented in Figure 2. It may be noted that the nitrogen uptake of the first crop from samples 3.LCSp, 4.CSp and 8.EuSCp has not been higher than the amount of mineral nitrogen present in the original samples. In the other samples mobilization of nitrogen has keen necessary to satisfy the needs of the first crop. Particularly marked this has been in sample 5.SCp in which the original content of mineral nitrogen was less than one half of that taken up by the first crop.

In the pot experiment the peat samples were kept at optimum moisture conditions for about three months in each year. Also the temperature was fairly high at 


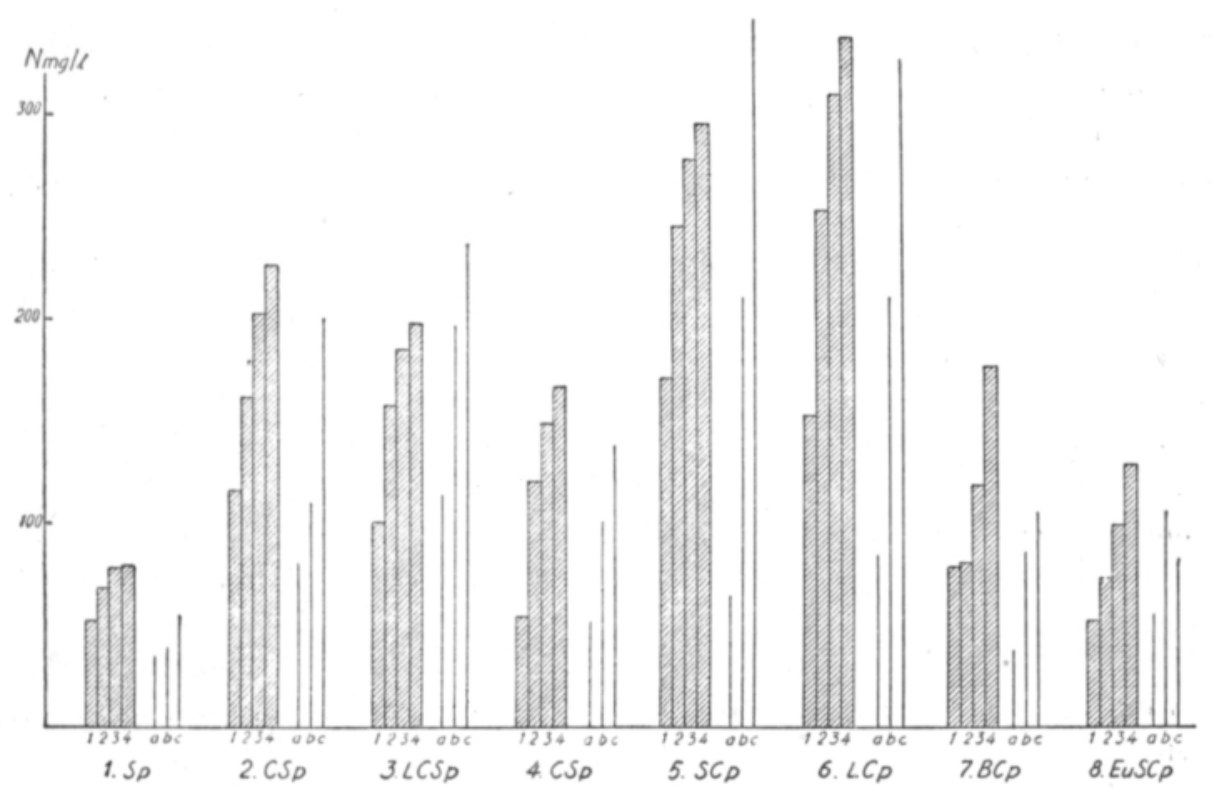

Fig. 2. $\mathrm{N}$ uptake by $1,2,3$, and 4 successive oat crops and the amounts of mineral $\mathrm{N}$ in the original peat samples (a) and in samples incubated at $10-15^{\circ} \mathrm{C}$ for one month (b) and at $7^{\circ} \mathrm{C}$ for 4 months.

least part of the growing season. Thus the conditions were favourable for mineralization processes. Yet, the uptake of nitrogen by the first crop from all but the sample 1.Sp was markedly lower than the amount of mineral nitrogen accumulated in the samples incubated for four months at $7^{\circ} \mathrm{C}$. Even the quantities of mineral nitrogen in most of the samples incubated for one month at $10-15^{\circ} \mathrm{C}$ are distinctly higher that the amount of plant nitrogen which originated from the peat. The data for the mineral nitrogen in samples incubated for six months at the higher temperature are markedly higher than the total uptake of nitrogen by all the four successive oat crops except in samples 1.Sp and 8.EuSCp in which the corresponding data are equal.

These results point at the possibility that the plants have not been able to utilize all the nitrogen mineralized during the growing periods. There is, of course, also the possibility that peat nitrogen has not been mobilized at the same rate in pot cultures as it was in the incubation experiments. If the former alternative is true it is likely that even marked losses of nitrogen have occurred in the pot experiment, particularly from the samples 2.SCp, 3.LCSp, 5.SCp and 6.LCp.

The probable losses of nitrogen in pot experiment may be attributed to some kind of denitrification or also to volatilization of ammonia. It is of importance to notice that the mixtures of peat and sand into which also lime was applied were only very slightly acid or almost neutral. In the end of the first growing period the $\mathrm{pH}$ values measured in water-suspension (1:4) were the following:
1.Sp $\quad \mathrm{pH} 6.8$
$5 . \mathrm{SCp} \quad \mathrm{pH} 6.3$
2.CSp $\quad \mathrm{pH} 6.4$
6.LCp $\quad \mathrm{pH} 6.4$
3.LCSp $\quad \mathrm{pH} 6.2$
7.BCp pH 6.8
4.CSp pH 6.2
8.EuSCp pH 7.0 
Since volatilization of ammonia occurs intensively only from substrates with a $\mathrm{pH}$ higher than 6.5 (5), most liable to this kind of nitrogen losses were samples 1.Sp, 7.BCp, and 8.EuSCp. It must be taken into account that also in the incubation experiments the limed samples were only slightly acid. Thus even there some loss of ammonia was possible.

Owing to the fairly high nitrogen content of the peat samples, it is not probable that microbiological immobilization of mineral nitrogen played any important role in these experiments. Since also the roots were removed not even the decomposition of this material could bind mineral nitrogen. Some attention must be paid to the source of energy and carbonaceous substance the microorganisms in the pot cultures had in root excretion and in dying off root cells. However, it is not likely that the differences in the results of incubation expriments and pot cultures could be explained on the basis of the higher immobilization of mineral nitrogen in the pot cultures.

The highest amounts of nitrogen were taken up by the first crop and most of the succeeding crops obviously suffered from the lack of available nitrogen. It is likely that the most intensive mineralization occurred in the beginning of the pot experiment. In that period there probably was available nitrogen enough for the need of the young plants. Later, owing to the possible losses of nitrogen and a slower rate of mineralization deficiency of available nitrogen could appear.

It is, of course, not excluded that the poor growth of most of the later crops was not due to the lack of available nitrogen. A deficiency of some other nutrient hardly played any role. An accumulation of injurious products of root metabolism, on the other hand, may form one reason which deserves attention.

\section{Discussion}

The results of this pot experiment in which the air-dried and ground peat samples acted as the only source of nitrogen do not quite agree with the earlier conception that the Carex-peats are superior to the Sphagnum-peats, particularly in regard to their nitrogen availability. According to the present results the uptake of nitrogen by the oat crops from these samples corresponded to the following amounts of nitrogen, expressed as $\mathrm{kg} / \mathrm{ha}$ in a $20 \mathrm{~cm}$ layer:

$\begin{array}{lccc}\text { Sample } & \text { Bo } & \text { N uptake, 1. year } & \text { N uptake, total } \\ & & & \\ \text { 6.LCp } & 7 & 300 & 670 \\ \text { 5.SCp } & 6 & 340 & 590 \\ \text { 2.CSp } & 2 & 230 & 450 \\ \text { 3.LCSp } & 2-3 & 200 & 390 \\ \text { 7.BCp } & 7 & 150 & 350 \\ \text { 4.CSp } & 3 & 110 & 330 \\ \text { 8.EuSCp } & 8 & 100 & 250 \\ \text { 1.Sp } & 1 & 100 & 160\end{array}$

The total yields of grain and straw produced by the peat samples were in the same mutual order as the amounts of nitrogen taken up from the peat. 
The fairly good achievement of sample 2.CSp on the one hand, and the relatively poor performance of sample 7.BCp, and particularly of sample $8 . \mathrm{EuSC}$, on the other hand, are most surprising. It may be claimed that these peat samples were not very typical representatives of their groups. Also it is possible that samples with a higher degree of humification would give "more probable" results. It must also be remembered that differences in the physical properties in the structure, in the moisture conditions etc., were eliminated.

It is generally assumed that the Finnish peat soils are poor in phosphorus but rich in nitrogen. This is true in regard to the total amounts of these nutrients. Numerous experiments in the field and practical experience usually corroborate this opinion. Under the abnormal conditions of the pot experiment, however, other kinds of results may be obtained. In a previous paper (2) the junior author dealt with a pot experiment which was equal to the pot cultures of the present study except that in it nitrogen fertilizers were applied and the plants grew with peat as the only source of phosphorus. It is of interest to compare the yields of these two experiments. The total grain and straw yields harvested in the first year were the following (expressed as $\mathrm{g} / \mathrm{pot}$ ):

\begin{tabular}{|c|c|c|c|c|c|c|c|c|}
\hline & 1.Sp & 2.CSp & 3.LCSp & 4.CSp & 5.SCp & 6. $\mathrm{LC}_{\mathrm{p}}$ & 7. $\mathrm{BCp}$ & 8. $\mathrm{EuSC}_{\mathrm{P}}$ \\
\hline Without $N$ & 10 & 16 & 11 & 8 & 16 & 13 & 13 & 10 \\
\hline $\mathrm{P}$ & 15 & 24 & 12 & 10 & 24 & 21 & 19 & 21 \\
\hline
\end{tabular}

Thus, in all the pots the yield produced by the peat phosphorus was higher than that produced by the peat nitrogen. Later on, the differences decreased, but even the total yields of three successive crops were higher when produced by the native phosphorus in the samples 5.SCp, 6.LCp and 8.EuSCp than the corresponding yields produced by the peat nitrogen.

This result may be explained supposing that the production of organic matter depends more on the nitrogen supply than on the supply of phosphorus. It seems not to be justifiable to claim that the pretreatment of the samples, it is air-drying and grinding, would have made the peat phosphorus relatively more available than the peat nitrogen. On the contrary, the experimental results indicate that air-drying and grinding are apt for a mobilization of peat nitrogen, but that these treatments generally decrease the solubility of peat phosphorus (cf. 4).

\section{$S u m m a r y$}

Results are reported of a pot experiment in which four successive oat crops were grown with peat as the only source of nitrogen. Eight samples from virgin peat lands representing different land qualities were used. The samples were air-dried and ground which is known to increase markedly the amount of ammonium nitrogen in peat. Some data from incubation experiments were compared with the uptake of peat nitrogen by plants. 
The results did not agree with the earlier conception that the Carex-peats are superior to the Sphagnum-peats, particularly in regard to the availability of peat nitrogen. Under the conditions of pot culture and incubation experiments some of the fairly poor Carex-Sphagnum peats were markedly better as supplyers of nitrogen to the plants than were e.g. samples of Bryales-Carex peat and eutrophic SphagnumCarex peat of the present study.

The uptake of nitrogen by plants from the peat samples was often lower than the amounts of mineral nitrogen accumulated in short-time incubation experiments. The possible reasons for this discrepance was discussed.

It was pointed out that in pot experiments these air-dried and ground peat proved to produce higher yields without phosphorus fertilizers than without application of nitrogen, at least in the first year.

\section{REFERENCES}

(1) Jansson, S. L. 1958. Tracer studies on nitrogen transformations in soil with special attention to mineralisation-immobilization relationships. Rep. Ann. Roy. Agr. Coll. Sweden 24: $101-361$.

(2) KaIl A, A. 195 . Availability to plants of phosphorus in some virgin peat samples. J. Sci. Agric. Soc. Finland 30: 133-142.

(3) $\rightarrow-$ SoINI, S. \& Krvinen, E. 1954. Influence of lime and fertilizers upon the mineralization of peat nitrogen in incubation experiments. Ibid. 26: 79-95.

(4) KıvEKäs, J. 1958. Turvenäytteiden kuivaamisen ja jauhamisen vaikutuksesta analyysituloksiin. (Summary: The effect of drying and grinding of peat samples on the results of analyses). Ibid. 30: $1-9$.

(5) TUORILA, P. 1929. Bindungsvermögen verschiedener Torfarten für Stickstoff in Form von Ammoniak. Wissensch. Veröffentl. Finn. Moorkulturver. No 9. Helsinki, 24 p.

S E L O T U S :

TURVE TYPEN LÄHTEENÄ ASTIAKOKEESSA

Erkki Kivinen ja Armi Kaila

Yliopiston maanviljelyskemian laitos, Helsinki

Tutkimuksessa esitetään tuloksia astiakokeesta, jossa kasvatettiin neljä perättäistä kaurasatoa turve ainoana typenlähteenä. Aineistona oli kahdeksan luonnontilaisilta soilta kerättyä näytettä, jotka edustivat boniteetteja $\mathbf{1}-\mathbf{8}$. Näytteet oli kuivatettu huoneen lämpötilassa ja jauhettu. Tuloksia verrattiin muhituskokeissa kertyneisiin typen määriin.

Todettiin, etteivăt astiakokeen tulokset olleet yhtäpitäviä vallitsevan käsityksen kanssa, jonka mukaan saraturpeitten typpi olisi helpommin käytettävissä kuin rahkavaltaisten turpeiden. Sekä astiakokeessa että muhituksessa osoittautui pari CS-turvetta yllättävän hyväksi kasvualustaksi, kun taas BC-turve ja etenkin EuSC-turve antoivat huonot sadot.

Lyhytaikaisissakin muhituskokeissa kertyi usein enemmän mineraalityppeä kuin kasvit ottivat astiakokeessa. Tämän selitykseksi on esitetty eri mahdollisuuksia.

Havaittiin myös, että nämä kuivatetut ja jauhetut turvenäytteet tuottivat suhteellisesti suuremman sadon ilman fosforilannoitteita kuin ilman typpilannoitteita, ainakin ensimmäisenä vuotena. 